\title{
The effects of oxygen radicals on the activity of nitric oxide synthase and guanylate cyclase
}

\author{
Suk-mo Kim ${ }^{1}$, Ji-soo Byun ${ }^{1}$, Young-do Jung ${ }^{2}$, \\ In-chol Kang ${ }^{3}$, Suk-yong $\mathrm{Choi}^{2}$ and \\ Kee-Young Lee Le $^{2,4}$ \\ 1 Department of Obstetrics and Gynecology, Chonnam University Medical School; \\ Chonnam University Research Institute of Medical Sciences, Kwangju 501-190, \\ Korea \\ 2 Department of Biochemistry, Chonnam University Medical School; Chonnam \\ University Research Institute of Medical Sciences, Kwangju 501-190, Korea \\ 3 Department of Oral Microbiology, Chonnam University Dental School, Kwangju 501- \\ 190, Korea \\ 4 Corresponding author: Phone, 82-62-220-4103; Fax, 82-62-223-8321; \\ E-mail, kylee@orion.chonnam.ac.kr
}

Accepted 23 September 1998

Abbreviations: NOS, nitric oxide synthase; GC, guanylate cyclase; NBT, nitroblue tetrazolium; MCO, metal-catalyzed oxidation; ABAP, 2'2'-azobis- amidinopropane; SNP, sodium nitroprusside; NAME, L-nitroarginine methyl ester; X/XO, xanthine/xanthine oxidase dose-dependent manner from $100 \mu \mathrm{M}$ to $1 \mathrm{mM}$ without significant effects on NOS. $\mathrm{H}_{2} \mathrm{O}_{2}$-induced GC activation was blocked by catalase. These results suggested that oxygen radicals inhibited NOS and $\mathrm{GC}$, but $\mathrm{H}_{2} \mathrm{O}_{2}$ could activate $\mathrm{GC}$ directly.

Keywords: Oxygen radicals, hydrogen peroxide, NO synthase, guanylate cyclase

\section{Introduction}

Oxygen radicals are the reactive oxygen deriviatives with unpaired electrons generated from an oxygen molecule $\left(\mathrm{O}_{2}\right)$. Molecular oxygen is reduced to a superoxide radical $\left(\cdot \mathrm{O}_{2}{ }^{-}\right)$and this radical is readily converted to hydrogen peroxide $\left(\mathrm{H}_{2} \mathrm{O}_{2}\right)$ by superoxide dismutase (SOD). $\mathrm{H}_{2} \mathrm{O}_{2}$ is also reduced to a hydroxyl radical $(\cdot \mathrm{OH})$ in the presence of a transient metal ion. These reactive oxygen species are considered as endogenous toxicants which cause acute cell demage in a variety of pathological conditions such as ischemia-reperfusion injury, cancer and the aging process (Knight, 1995). However, it has been suggested that oxygen radicals may act as modulators in signal trans-duction (Landle, 1997). Attenuation of coronary artery dilatation by SOD suggested that superoxides may be involved in the control of blood pressure (Burke et al., 1991). While hydrogen peroxide also causes dilatation of the cerebral and pulmonary arteries (Ignarro et al., 1987, Bredt and Snyder 1989). In addition, reactive oxygens were generated in the processing of signal transduction of growth factors and hormones (Bae et al., 1997).

$\mathrm{NO}$, a novel messenger, is involved in a variety of important physiological processes including vascular relaxation, neuronal transmission, immune responses and hemostasis (Palmer et al., 1987; Bredt and Snyder, 1989; Kwon et al., 1989). NO synthase enzymes are divided into two major isoforms. The constitutive NOS occuring in brain and endothelial cells has bound FAD, FMN and requires $\mathrm{Ca}^{2+}$, calmodulin, NADPH and tetrahydrobiopterin as cofactors (Mayer et al., 1991). The other enzyme is an inducible form found in several cell types including macrophages and vascular smooth muscle in response to cytokines and bacterial toxins. The inducible NOS is different from the constitutive form by a $\mathrm{Ca}^{2+} /$ calmodulin-independency on enzyme activity (Stuehr et al., 1989).

Mittal (1993) reported that exogenous catalase reduced NOS activity suggesting that hydrogen peroxide and superoxide radical are involved in enhancing NOS activity with the following reasons as the basis of his 
proposal. First, NOS catalyzes not only NO formation but also accelerates various oxido-reduction reactions. As NADPH diaphorase NOS has been known to reduced nitroblue tetrazolium (Mayer et al., 1991). Secondly, purified NOS can directly catalyze the generation of oxygen radicals at suboptimal concentrations of arginine and tetrahydropterin. NOS from rats brains has been shown to mimic the activity of $\mathrm{Ca}^{2+} /$ calmodulindependent NADPH oxidase in the production of hydrogen peroxide and superoxide (Heinzel et al., 1992). Finally, in the process of arginine conversion to NO, Larginine is oxidized to $\mathrm{N}-\mathrm{OH}$ - $\mathrm{L}$-arginine, the first intermediate in the presence of molecular oxygen (Stuehr et al., 1991). To the contrary, many reports also (Liu et al., 1994; Miyamoto et al., 1996) suggested that oxygen radicals could inhibit GC by scavenging NO to produce peroxynitrite.

The present study was undertaken to clarify the effects of various oxygen radicals on the NOS and GC activity with oxygen radical scavengers and oxygen radicalgenerating systems.

\section{Materials and Methods}

\section{Chemicals}

L-Arginine, 2'2'-azobis-amidinopropane (ABAP), NADPH, calmodulin, sodium nitroprusside (SNP), L-nitroarginine methyl ester (NAME), creatine phosphate, theophylline, GTP, lipopolysaccharide (LPS), interferon- $\gamma$ (INF- $\gamma$ ) and creatine phosphokinase were purchased from Sigma (USA). L-[2,3,4- $\left.{ }^{3} \mathrm{H}\right]$-arginine- $\mathrm{HCl}$ and cGMP assay kits were sourced from Amersham (UK), and fetal bovine serum (FBS) and RPMI medium were from Gibco-BRL (USA). All other reagents were of analytical grade.

\section{Preparation of enzyme extracts}

Sprague-Dawley rats (150-200 g) were killed by decapitation. Whole brains were quickly removed, cleaned and immersed in ice-cold $0.25 \mathrm{M}$ sucrose. The brains were homogenized in 6 volumes (w/v) of $0.25 \mathrm{M}$ sucrose containing $20 \mathrm{mM}$ Tris- $\mathrm{HCl}$ (pH 8.0), $1 \mathrm{mM}$ EDTA, $1 \mathrm{mM}$ dithiothreitol (DTT), phenylmethylsulfonyl fluoride (PMSF, $100 \mu \mathrm{g} / \mathrm{ml})$, leupeptin $(10 \mu \mathrm{g} / \mathrm{ml})$, pepstatin (10 $\mu \mathrm{g} / \mathrm{ml})$ and soybean trypsin inhibitor $(10 \mu \mathrm{g} / \mathrm{ml})$ at $4^{\circ} \mathrm{C}$ using a glass homogenizer with a Teflon pestle. To examine the metal-catalyzed oxidation (MCO) effects on the enzyme activity, EDTA was excluded from the standard homogeni-zing solution. The homogenate was centrifuged at $18,000 \mathrm{~g}$ for $15 \mathrm{~min}$. The supernatant was stored at $-70^{\circ} \mathrm{C}$ and used as source for NOS and GC.

\section{Activation of $\mathbf{J 7 7 4}$ cells by LPS and INF- $\gamma$}

J774 cells were grown in RPMI 1640 supplemented with $10 \%$ FBS, penicillin $(100 \mathrm{U} / \mathrm{ml})$ and streptomycin (100 $\mu \mathrm{g} / \mathrm{ml}$ ) as described by Cunha et al. (1993). Cells at a density of $10^{5}$ cells $/ \mathrm{ml}$ were treated with LPS $(10 \mu \mathrm{g} / \mathrm{ml})$ and INF- $\gamma(100 \mathrm{U} / \mathrm{ml})$ for activation. After incubation for $12 \mathrm{~h}$, cells were harvested in $0.25 \mathrm{M}$ sucrose containing $20 \mathrm{mM}$ Tris-HCl (pH 8.0), 1 mM EDTA, 1 mM DTT, PMSF $(100 \mu \mathrm{g} / \mathrm{ml})$, leupeptin $(10 \mu \mathrm{g} / \mathrm{ml})$, pepstatin $(10 \mu \mathrm{g} / \mathrm{ml})$ and soybean trypsin inhibitor $(10 \mu \mathrm{g} / \mathrm{ml})$ at a cell count of $10^{7} / \mathrm{ml}$. After sonication for $20 \mathrm{sec}$, a supernatant was acquired for iNOS enzyme solution by centrifugation at $18,000 \mathrm{~g}$ for $15 \mathrm{~min}$.

\section{Determination of NOS activity}

NOS activity was determined by the conversion of $L-\left[{ }^{3} \mathrm{H}\right]$ arginine to $L-\left[{ }^{3} \mathrm{H}\right]$ citrulline according to Bredt and Snyder (1989). The reaction mixture contained $50 \mathrm{mM}$ Tris- $\mathrm{HCl}$ (pH 7.6), 2 mM calcium chloride, $20 \mu \mathrm{M}$ NADPH, $20 \mu \mathrm{M}$ L-arginine, approximately $150,000 \mathrm{cpm}$ of $\mathrm{L}-\left[2,3,4-{ }^{3} \mathrm{H}\right]$ arginine- $\mathrm{HCl}(0.2 \mu \mathrm{Ci})$ and $100 \mu \mathrm{g}$ of enzyme protein in a final incubation volume of $100 \mu \mathrm{l}$. For the iNOS activity assay, FAD (10 $\mu \mathrm{M})$ and (6R)-5,6,7,8-tetrahydrobiopterin $(0.1 \mu \mathrm{M})$ were added and calcium chloride was removed from the reaction mixture. Enzyme reactions were carried out at $37^{\circ} \mathrm{C}$ for $8 \mathrm{~min}$ and terminated by the addition of $400 \mu \mathrm{l}$ of Stop Buffer (20 mM sodium acetate, $\mathrm{pH} 5.5,2$ $\mathrm{mM}$ EGTA and $1 \mathrm{mM}$ L-citrulline). The reaction mixture $(0.5 \mathrm{ml})$ generated, was applied over $1 \mathrm{ml}$ of Dowex AG (50W-X8, Na+ form, 100-200 mesh) which was preequilibrated with Stop Buffer. Colummns were eluted with additional $2 \mathrm{ml}$ of water (4 fractions of $0.5 \mathrm{ml}$ each). To each vial, $2 \mathrm{ml}$ of a scintillation mixture was added prior to assessment in a liquid scintillation counter.

\section{Assay of GC activity}

GC activity in brain cytosol was determined according to Mittal (1993). The standard reaction mixture $(100 \mu \mathrm{l})$ contained $50 \mathrm{mM}$ Tris- $\mathrm{HCl}(\mathrm{pH} 7.6), 15 \mathrm{mM}$ creatine phosphate, $20 \mu \mathrm{g}$ of creaine phosphokinase (120 units/ mg protein), $8 \mathrm{mM}$ theophilline, $4 \mathrm{mM} \mathrm{MgCl}_{2}$ and $100 \mu \mathrm{g}$ brain cytosolic protein. For activation of GC, NADPH $(100 \mu \mathrm{M})$ and arginine $(100 \mu \mathrm{M})$ with or without an NO donor (sodium nitroprusside) was added. Reactions were initiated by the addition of $1 \mathrm{mM}$ GTP and continued for $10 \mathrm{~min}$ at $37^{\circ} \mathrm{C}$ before termination by the addition of 50 $\mathrm{mM}$ of sodium acetate $(\mathrm{pH} 4.0)$ at $4^{\circ} \mathrm{C}$. Tube contents were heated in boiling water for 3 min for deproteination and cyclic GMP formed was determined using a radioimmunoassay kit (Amersham Life Sci., U.K.).

\section{Results}

\section{Effects of antioxidants and oxygen radicals on NOS}

To investigate the involvement of antioxidants and oxygen radicals on NOS, nNOS in rat brains and iNOS of 
murine macrophage $\mathrm{J} 774$ cell lines were employed. SOD and catalase did not significantly change NOS activity, but POD and NBT inhibited both nNOS and iNOS activity (Figure 1a, b). POD and NBT inhibited NOS activity in a dose-dependent manner (data not shown). NBT was known to interact with superoxide ions and reduce them to formazan (Mittal, 1993). As shown in Figure 2, the inhibitory action of POD or NBT was removed by increasing the concentration of NADPH and arginine, respectively. Oxygen radical generating systems also inhibited NOS to a different degree (Figure 3). Xanthine/xanthine oxidase (X/XO, a superoxide ion generating system) inhibited NOS activity by $90 \%$ and

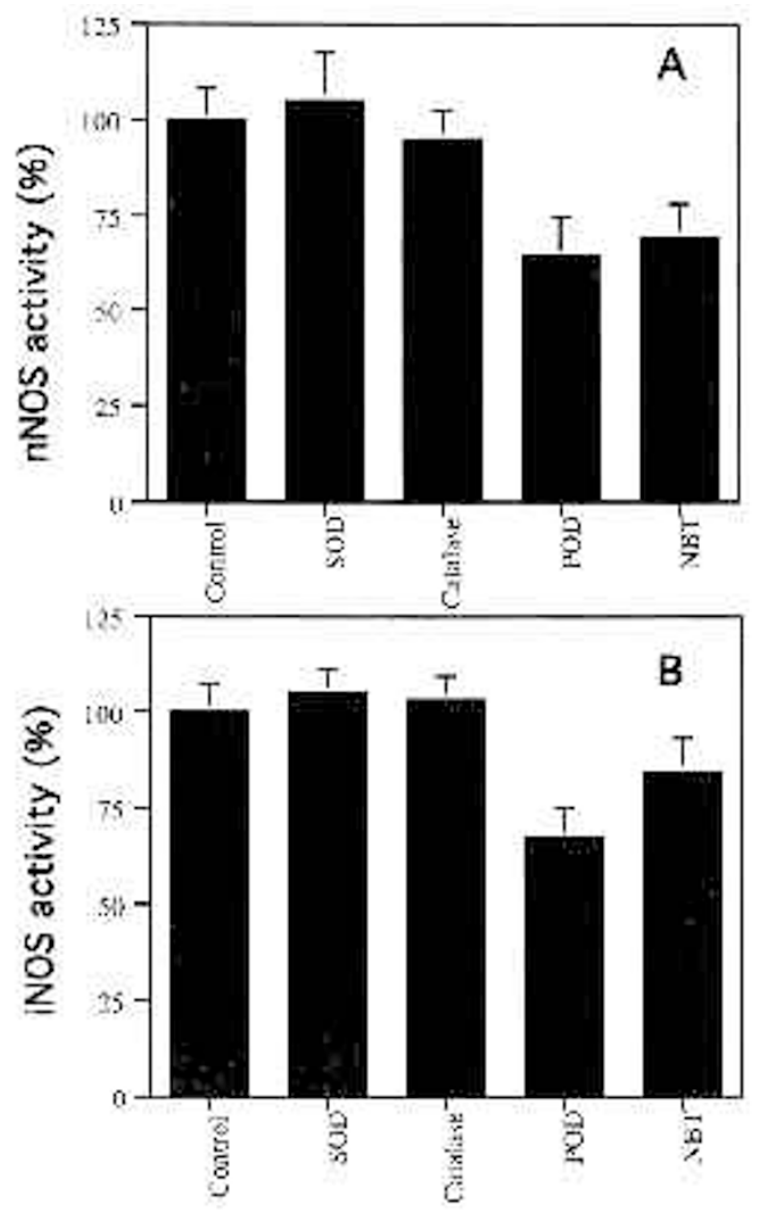

Figure 1. Effects of oxygen radical scavengers on $n N O S(A)$ and iNOS (B) activities. Enzyme preparation $(100 \mu \mathrm{g})$ was incubated with $20 \mu \mathrm{M}$ NADPH, $20 \mathrm{mM}$ L-arginine, $\left[{ }^{3} \mathrm{H}\right]$ arginine $(150,000 \mathrm{cpm})$ and various oxygen radical scavengers in a reaction mixture for $10 \mathrm{~min}$ at $37^{\circ} \mathrm{C}$ as described under 'Materials and Methods'. The $\left[{ }^{3} \mathrm{H}\right] \mathrm{citrulline}$ formation was determined for NOS activity. The oxygen radical scavenging systems were as follows; SOD (100 U), catalase (2,000 U), POD (30 U) and NBT (100 $\mu \mathrm{M})$. The control neuronal and inducible NOS activity was 0.14 and $0.37 \mathrm{nmole} / \mathrm{mg} / \mathrm{min}$, repectively. Results are presented as the means \pm SD of triplicate experiments.
MCO and ABAP (a temperature-dependent peroxy radical generator) inhibited it by $33 \%$ and $47 \%$, respectively. However, hydrogen peroxide did not significantly alter NOS activity. The effects of antioxidants and oxygen radicals on iNOS were almost similar as to those on nNOS.

\section{Effects of antioxidants and oxygen radicals on GC}

Rat brain GC was activated either by NOS reactions or SNP, a NO donor (data not shown). In the NOS-dependent activation of GC, POD inhibited GC activity by $15 \%$ and this inhibitory action was blocked by increasing the concentration of NADPH. MCO, ABAP and X/XO systems inhibited NOS-mediated GC activation by $13 \%, 27 \%$ and $57 \%$, respectively (Figure 4). GC activated by SNP was inhibited by $\mathrm{MCO}$ and $\mathrm{X} / \mathrm{XO}$ systems by $15 \%$ and $37 \%$, respectively. In these experimental conditions, $100 \mu \mathrm{M}$ LAME reduced NOS-dependent GC activation to less than $5 \%$, but POD or ABAP did not inhibit SNP-mediated GC activity (Figure 5).

\section{Activation of GC by oxygen radicals}

Figure 6 shows that hydrogen peroxide activates rat brain GC in a dose dependent manner, albeit at a supraphysiologic concentration without NO generation systems. To prevent NO formation, NOS was blocked by the

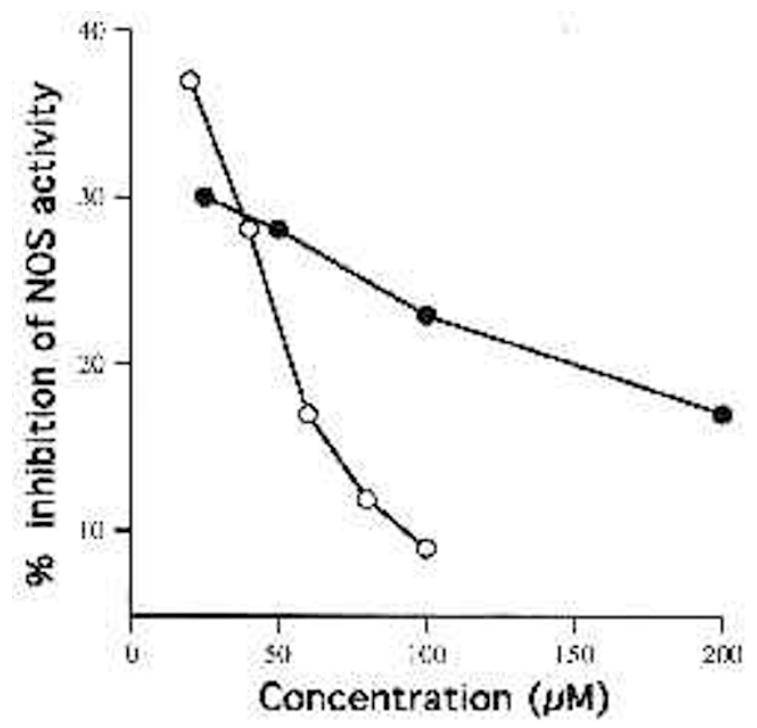

Figure 2. Effects of NADPH and L-arginine on POD $(\bigcirc-\bigcirc)$ - and NBT )-induced NOS inactivation, respectively. Rat brain cytosolic fraction $(100 \mu \mathrm{g})$ was incubated with $30 \mathrm{U}$ of POD and $100 \mu \mathrm{M}$ NBT with various concentrations of NADPH and $\mathrm{L}$-arginine in a reaction mixture as described under 'Materials and Methods' and $\left[{ }^{3} \mathrm{H}\right]$ citrulline formation was determined for NOS activity as Figure 1. Values are means of duplicate experiments. 

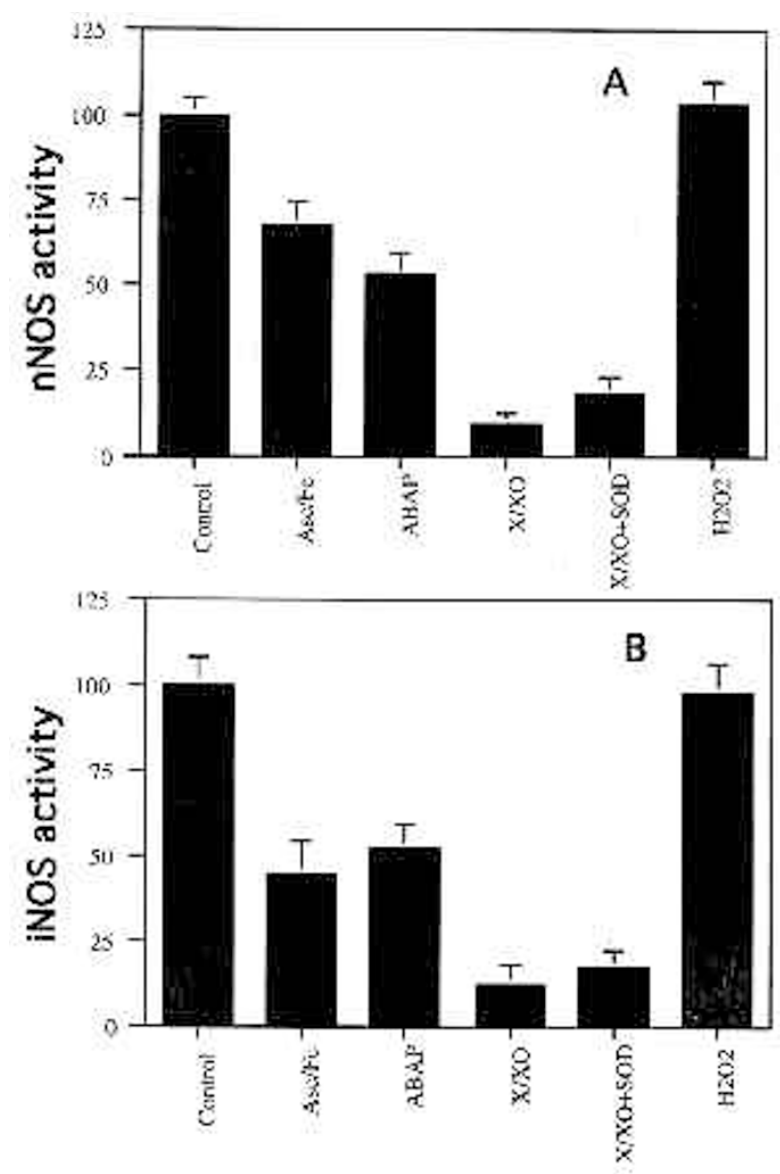

Figure 3. Effects of reactive oxygen radicals on nNOS (A) and iNOS (B) activities. Enzyme preparation $(100 \mu \mathrm{g})$ was incubated with various oxygen radical generating systems in a reaction mixture as described under 'Materials and Methods' and $\left.{ }^{3} \mathrm{H}\right] \mathrm{citrulline}$ formation was determined for NOS activity as Figure 1. The oxygen radical generation systems are as follows; Asc/Fe (1 mM ascorbate/10 $\mu \mathrm{M} \mathrm{Fe}), \mathrm{ABAP}(5 \mathrm{mM})$, xanthine/xanthine oxidase $\left(X / X O, 1 \mathrm{mM} / 5 \times 10^{-3} \mathrm{U}\right)$ with or without $\operatorname{SOD}(100 \mathrm{U})$, and $\mathrm{H}_{2} \mathrm{O}_{2}(100 \mu \mathrm{M})$. Results are presented as the means $\pm \mathrm{SD}$ of triplicate experiments.

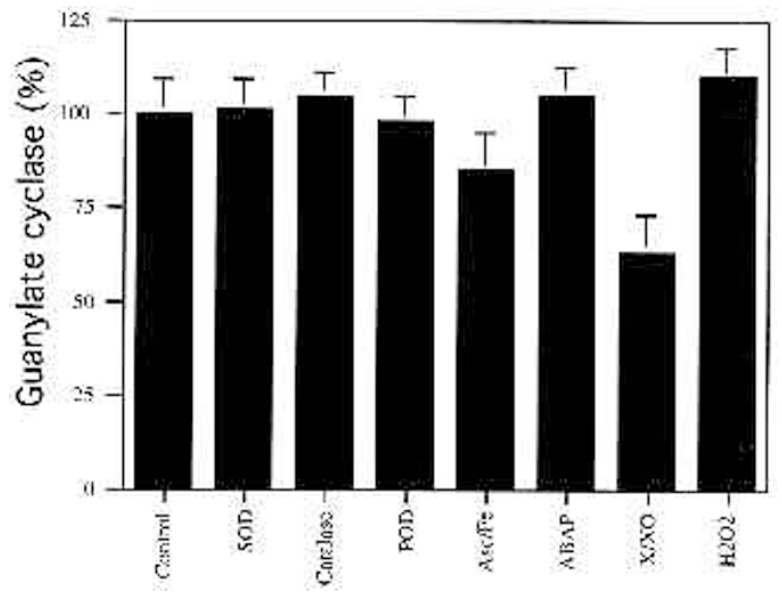

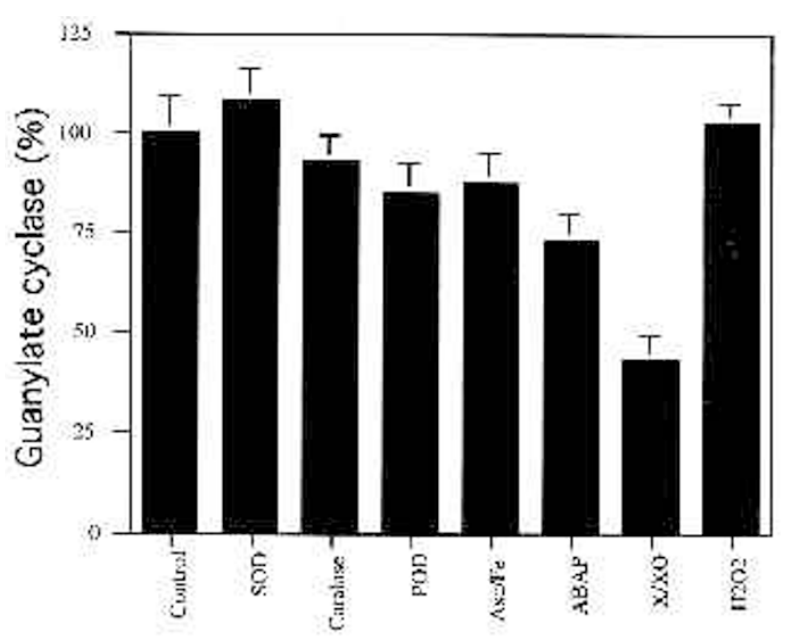

Figure 4. Effects of oxygen radicals and oxygen radical scavengers on NO-mediated GC activation. Rat brain cytosolic fraction $(100 \mu \mathrm{g})$ was incubated with various oxygen radical generation systems and antioxidant systems in a reaction mixture containing 20 $\mu \mathrm{M}$ L-arginine, $20 \mu \mathrm{M}$ NADPH, $15 \mathrm{mM}$ creatine phosphatase, $20 \mu \mathrm{g} / \mathrm{ml}$ creatine phosphokinase (120 U/mg protein), $4 \mathrm{mM}$ theophylline, $4 \mathrm{mM} \mathrm{MgCl}$, and $1 \mathrm{mM} \mathrm{GTP} \mathrm{for}$ $\mathrm{GC}$ as described under 'Materials and Methods' for $10 \mathrm{~min}$ at $37^{\circ} \mathrm{C}$. The oxygen radical scaverngers and generation systems are as follow; SOD $(100 \mathrm{U})$, catalase $(2,000 \mathrm{U})$, $\mathrm{POD}(30 \mathrm{U}), \mathrm{Asc} / \mathrm{Fe}(1 \mathrm{mM}$ ascorbate/10 $\mu \mathrm{M} \mathrm{Fe}), \operatorname{ABAP}(5 \mathrm{mM})$, xanthine/xanthine oxidase $\left(X / X O, 1 \mathrm{mM} / 5 \times 10^{-3} \mathrm{U}\right)$ and $\mathrm{H}_{2} \mathrm{O}_{2}(100 \mu \mathrm{M})$. The cGMP formed was measured for $\mathrm{GC}$ activity by radioimmunoassay. Results are presented as the means \pm SD of triplicate experiments.

addition of L-NAME, and activation of GC by hydrogen peroxide was prevented by catalase. Oxygen radicals produced by MCO also activated GC, but to a lesser degree than hydrogen peroxide (data not shown).

\section{Discussion}

This study investigated the effects of antioxidants and oxygen radicals on NOS and GC activity. Some reports (Burke et al., 1991; Mittal, 1993) suggested that antioxidants could activate NOS, however, they employed the activation of isolated GC or the relaxation of smooth

Figure 5. Effects of oxygen radicals and oxygen radical scavengers on SNP-mediated GC activation. Rat brain cytosolic fraction $(100 \mu \mathrm{g})$ was incubated with various oxygen radical generation systems and antioxidant systems in a reaction mixture containing 100 $\mu \mathrm{M}$ SNP, $100 \mu \mathrm{M}$ L-NAME, $15 \mathrm{mM}$ creatine phosphatase, $2.4 \mathrm{U}$ creatine

phosphokinase, $4 \mathrm{mM}$ theophylline, $4 \mathrm{mM} \mathrm{MgCl}$, and $1 \mathrm{mM} \mathrm{GTP}$ for $\mathrm{GC}$ as described under 'Materials and Methods' for $10 \mathrm{~min}$ at $37^{\circ} \mathrm{C}$. The oxygen radical scavengers and generation systems are as follow; SOD (100 U), bovine liver catalase (2,000 U), POD $(30 \mathrm{U}), \mathrm{Asc} / \mathrm{Fe}(1 \mathrm{mM}$ ascorbate/10 $\mu \mathrm{M} \mathrm{Fe}), \mathrm{ABAP}(5 \mathrm{mM})$, xanthine/xanthine oxidase ( $\left.\mathrm{X} / \mathrm{XO}, 1 \mathrm{mM} / 5 \times 10^{-3} \mathrm{U}\right)$ and $\mathrm{H}_{2} \mathrm{O}_{2}(100 \mu \mathrm{M})$. The cGMP formed was measured as described in Figure 4. Results are presented as the means \pm SD of triplicate experiments. 


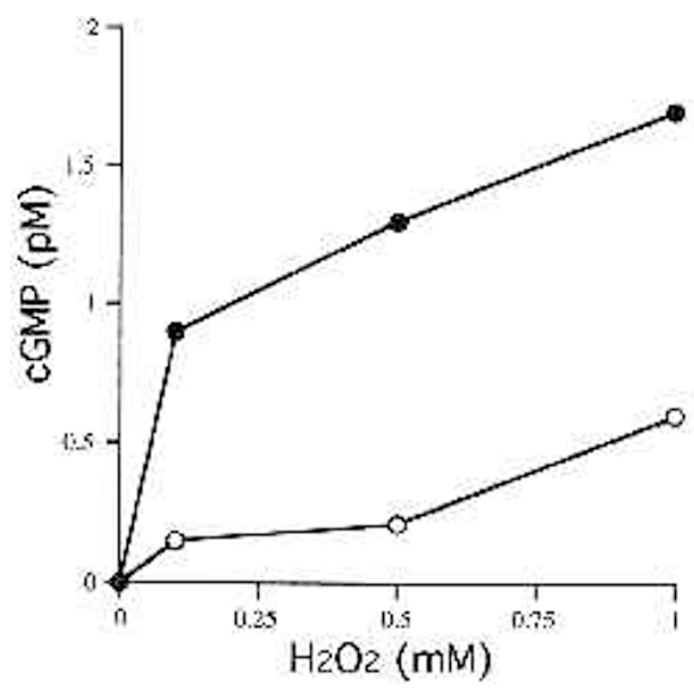

Figure 6. Effects of catalase on $\mathrm{H}_{2} \mathrm{O}_{2}$-mediated $\mathrm{GC}$ activation. Rat brain cytosolic fraction $(100 \mu \mathrm{g})$ was incubated with various concentrations of $\mathrm{H}_{2} \mathrm{O}_{2}$ with $(\mathrm{O}-\mathrm{O}$ ) or without $(-)$ catalase $(2,000 \mathrm{U})$ and in a reaction mixture containing $100 \mu \mathrm{M}$ L-NAME, $15 \mathrm{mM}$ creatine phosphatase, $2.4 \mathrm{U}$ creatine phosphokinase, $4 \mathrm{mM}$ theophylline, $4 \mathrm{mM} \mathrm{MgCl}_{2}$, and $1 \mathrm{mM} \mathrm{GTP}$ for GC as described under 'Materials and Methods'. The cGMP formed was measured as described in Figure 4. Values are means of duplicate experiments.

muscle as detector systems for NO formation. Therefore, there are some controversies that the direct effects of antioxidant or oxygen radicals on GC or on muscle relaxation rather than on NOS should have been studied. In this study, we detected $\mathrm{L}-\left[{ }^{3} \mathrm{H}\right]$ citrulline from $\mathrm{L}-$ $\left[{ }^{3} \mathrm{H}\right]$ arginine for NOS activity. The amount of formed citrulline is not affected, whereas that of produced NO or NO-mediated GC activation could be affected by oxidants or antioxidant. Superoxide radicals are known to convert NO to peroxy-nitrite (Huie et al., 1993). GC activity could be blocked by superoxide or hydroxyl radicals and enhanced by hydrogen peroxide as shown in this study. Exogenous SOD and catalase did not alter NOS activity, but horse-raddish peroxidase (POD) and NBT inhibited NOS activity significantly. The inhibitory effects of POD and NBT were attenuated by increasing the concentration of NADPH and arginine, respectively. $P O D$ accepts electrons from non-specific electron donors to dissipate hydrogen peroxide, so it could consume NADPH in the NOS reaction mixture, resulting in decreased NOS activity. The effects of NBT on NOS can be explained by the NADPH diaphorase acitivity of NOS. NBT, the substrate for the NADPH diaphorase reaction (Hope et al., 1991), could be able to compete with L-arginine, substrate for NOS. So the NBT in the reaction could act as a substrate competitor rather than as a superoxide scavenger.

Oxygen radicals produced by the MCO system included
ABAP and X/XO inhibited NOS. It is well-known that NOS is highly unstable and oxygen radicals can inactivate it. When stored at $0^{\circ} \mathrm{C}, 50 \%$ of the enzyme activity in purified NOS is lost in $2 \mathrm{~h}$, whereas the crude enzyme extracts lose $50 \%$ of its activity in 2 days. In this study, the data of non protection of the X/XO induced-inactivation of NOS by SOD suggests that other factors may be involved in inactivation other than superoxides. Molecular oxygen as one of the substrate of NOS may be responsible for enzyme activity rate. According to Rengasamy and Jones (1993), partial oxygen pressure at lower than $35 \mathrm{mmHg}$ decreases NOS activity. Taken together, oxygen radical generation systems could inhibit NOS either by oxidation of NOS or consumtion of molecular oxygen in the reaction.

The effects of antioxidants or oxygen radicals on NOS-mediated GC activity showed similar patterns to those on NOS but with less effects. These results indicate that the change in GC activity results from an alteration of NOS activity. The possibility that oxygen radicals could convert NO to peroxynitrite or other reactive nitrogen species before activating $\mathrm{GC}$ could not be ruled out. The inhibition of SNP-mediated GC activation by MCO or X/ XO (Figure 5) supports this assumption.

Mittal (1993) suggested that hydrogen peroxide is involved in enzyme activation by NOS, by showing that exogenous catalase abolished and SOD increased cGMP accumulation in the NOS reaction mixture of rat brains. In this system, exogenous catalase and SOD by themselves did not alter NOS activity. This discrepancy between the two studies may be due to different measuring systems, as mentioned above. Rengasamy and Jones (1994) insisted that exogenous hydrogen peroxide with catalase increased NOS activity by increasing $\mathrm{O}_{2}$ production without direct effects on NOS itself. In our study, hydrogen peroxide increased GC activity itself without association with NO. The results are consistent with earlier data (Burke et al., 1991; Ambrosio et al., 1994) which showed that oxygen radicals could increase cGMP and induced vasodilatation, suggesting that reactive oxygen species, especially hydrogen peroxide, might act as second messenger in vivo.

\section{Acknowledgement}

This work was supported by research fund from Chonnam University Research Institute of Medical Sciences (CURIMS 97-A-080).

\section{References}

Ambrosio, G., Golino, P., Pascucci, I., Rosolowsky, M., Campbell, W. B., DeClerkck, F., Tritto, I. and Chiariello, M. (1994) Modulation of platelet function by reactive oxygen metabolites. Am. J. Physiol. 267 (1 Pt 2): H308-318 
Bae, Y. S., Kang, S. W., Seo, M. S., Bains, I. C., Takle, E., Chock, P. B. and Rhee, S. G (1997) Epidermal growth factor (EGF) induced generation of hydrogen peroxide. J. Biol. Chem. 272: 217-221

Bredt, D. S. and Snyder, S. H. (1989) Nitric oxide mediates glutmate-linked enhancement of cGMP levels in the cerebellum. Proc. Natl. Acad. Sci. USA 86: 90309033

Burke, W. T. and Wolin, M. S. (1990) Inhibition of cGMP-associated pulmonary arterial relaxation to $\mathrm{H}_{2} \mathrm{O}_{2}$ and $\mathrm{O}_{2}$ by ethanol. Am. J. Physiol. 258: $\mathrm{H} 1267-1273$

Burke, W. T., Abate, C. J., Wolin, M. S. and Gurtner, G. H. H. (1991) Hydrogen peroxide-induced vasodialtation: role of guanosine $3^{\prime} 5$ ' cyclic monophosphate. Am. J. Physiol. 261: L393-398

Cunha, F. Q., Asseury, J., Xu, D., Charles, I., Liew, F. Y. and Moncada, S. (1993) Repeated induction of nitric oxide synthase and leishmanicidal activity in murine macrophages. Eur. J. Immunol. 23: 1385-1388

Heinzel, B., John, M., Klatt, P., Bohme, E. and Mayer B. (1992) $\mathrm{Ca}^{2+} /$ calodulindependent formation of hydrogen peroxide by brain nitiric oxide synthase. Biochem. J. 281: $627-630$

Hope, B. T., Michel, G. J., Knigge, K. M. and Vincent, S. R., (1991) Neuronal NADPH diaphorase is a nitric oxide xynthase. Proc. Natl. Acad. Sci. USA 88: 2811-2814

Huie, R. E. and Padmaga, S. (1993) The reaction of NO with superoxide. Free Radic. Res. Commun. 18: 195-199

Ignarro, L. J., Buga, G. M., Wood, K. S., Byrns, R. E. and Chaudhuri, G. (1987) Endothelium-derived relaxing factor produced and released from artery and vein as nitric oxide. Proc. Natl. Acad. Sci.USA 84: 9265-9267

Knight, J. A. (1995) Diseases related to oxygen-derived free radicals. Ann. Clin. Lab. Sci. 25: $111-121$

Kwon, N. S., Nathan, C. F. and Stuehr, D. J. (1989) Reduced biopterin as a cofactor in the generation of nitrogen oxide by murine macrophages. J. Biol. Chem. 264: 20496-
20501

Landle, H. M. (1997) An essential role for free radicals and derived species in signal transduction. FASEB J. 11: 118-124

Liu, S., Beckman, J. S. and Ku, D. D. (1994) Peroxynitirte, a product of superoxide and nitric oxide, produces coronary vasorelaxation in dog. J. Pharmacol. Exp. Ther. 268 $1114-1121$

Mayer, B., Hohn, M., Heinzel, B., Werner, E. R., Wachter, H., Schultz, G. and Bohme, E. (1991) Brain nitric oxide synthase is a biopterin and flavin-containing multi-functional oxido-reductase. FEBS Lett. 19: 187-191

Mittal, C. K. (1993) Nitric oxide synthase: involvement of oxygen radicals in conversion of L-arginine to nitric oxide. Biochem. Biophys. Res. Commun. 193: 126-132

Miyamoto, Y., Akaike, T., Yoshida, M., Goto, S., Horie, H. and Maeda, H. (1996) Potentiation of of nitiric oxide-mediated vasorelaxation by xanthine oxidase inhibitors Proc. Soc. Exp. Biol. Med. 211: 366-373

Palmer, R. M., Ferrige, A. G. and Moncada, S. (1987) Nitric oxide release accounts for the biologicval activity of endothelium-derived relaxing factor. Nature 327: 524-526

Rangasamy, A. and Johns, R. A. (1993) Inhibition of nitiric oxide synthase by a superoxide generating system. J. Pharmacol. Exp. Ther. 267: 1024-1027

Rangasamy, A. and Johns, R. A. (1994) Effect of hydrogen peroxide and catalase on rat cerebellum nitirc oxide synthase. Biochem. Pharmacol. 48: 423-425

Stuehr, D. J., Kwon, N. S., Gross, S. S., Thiel, B. A., Levi, R. and Nathan, C. F. (1989) Synthesis of nitrogen oxides from L-arginine by macrophage cytosol: requirement for inducible and constitutive components. Biochem. Biophys. Res. Commun. 161: 420-426

Stuehr, D. J., Kwon, N. S., Nathan, C. F., Griffith, O. W., Feldman, P. L. and Wiseman, J. (1991) N-omega-hydroxy-L-arginine is an intermediate in the biosynthesis of nitric oxide from L-arginine. J. Biol. Chem. 266: 6259-6263 